University of Nebraska - Lincoln

DigitalCommons@University of Nebraska - Lincoln

Publications of Center for Public Affairs

Research (UNO)

Public Policy Center, University of Nebraska

1989

School/Business Partnerships

James Dick

University of Nebraska at Omaha

James Marlin

University of Nebraska-Lincoln

Follow this and additional works at: https://digitalcommons.unl.edu/cpar

Part of the Public Affairs Commons

Dick, James and Marlin, James, "School/Business Partnerships" (1989). Publications of Center for Public Affairs Research (UNO). 8.

https://digitalcommons.unl.edu/cpar/8

This Article is brought to you for free and open access by the Public Policy Center, University of Nebraska at DigitalCommons@University of Nebraska - Lincoln. It has been accepted for inclusion in Publications of Center for Public Affairs Research (UNO) by an authorized administrator of DigitalCommons@University of Nebraska - Lincoln. 


\title{
School/Business Partnerships
}

\author{
James Dick \\ James Marlin
}

Business involvement in Nebraska schools has increased in recent years. This chapter compares types of school/business partnerships, explores their applications, and identifies models appropriate to Nebraska school districts and communities.

As our nation confronts the future of its school systems and dramatic economic changes, and as we quickly become part of an international economy, business leaders become increasingly concerned about reforming America's public schools. This commitment is more than philanthropy; it is enlightened self-interest, based on traditional public service responsibility and the promotion of a positive business image. There is a mixture of economic and humanitarian concerns, the need to get more for one's tax dollars, and the need to be certain that reliable, trained workers are available.

The report of the 74th American Assembly, a national meeting of educators, business leaders, and journalists, highlighted these problems as follows:

The prospects for American workers in the twenty-first century are mixed. American workers have experienced fifteen years of slack labor markets, stagnating income, intensifying import competition, and dislocation. A vital American economy that offers workers creative, rewarding work is absolutely attainable, but the conditions for such a scenario will require serious planning, work, and a resurgence of trust and cooperation among business, labor, and government. It will require a shift to an economic program that promotes not only investment in plant and equipment, but also investment in human capital. (Starr 1988)

This "investment in human capital" includes, among other things, America's school system. As business leaders look at schools today, they are concerned about whether they should attempt to influence or direct educational policies. These concerns were initially voiced by executives of large corporations in major American cities, but business leaders in smaller cities and rural areas are now exploring ways to foster school reform. This is part of the growing recognition that the private sector 
has a responsibility to participate in local, state, and national efforts to improve the public schools.

This chapter explores the role of business in education. Partnerships between schools and business are examined through a look at the history of business involvement in the schools and a general classification of school/business partnerships. Examples of national and state school/business partnerships, with special attention given to partnerships in rural areas, are identified. The nature of current school/business partnerships is discussed, as is the role of such partnerships in promoting economic development. The chapter concludes with policy recommendations regarding school/business partnerships in Nebraska.

\section{Business Involvement in the Schools}

Since the early 1900s, American businesses have had a special interest in the public schools. The schools were responsible for producing the workers needed for rapidly expanding industries; early vocational education programs focused on the development of specific job skills. Business leaders influenced the content of these programs and, in addition, urged that schools should be organized and managed like their offices and factories. This concern for the production of a skilled labor force continued until the 1960 s. There was little direct financial support to the schools from businesses other than taxes paid.

During the late 1960s and into the 1970s the educational climate was distinctly anti-establishment, so businesses had little to say about the operation of schools and the curriculum. Other local and national groups played dynamic roles in education reform, including the federal government, teachers unions, civil rights organizations, and special interest groups. The emphases of these reforms were equity, access, and community control. Many of these groups reflected the anti-business, anti-establishment mood of the era. Corporate leaders were rarely willing to serve on school boards, as it required working with volatile politi$\mathrm{cal}$ issues that required enormous outlays of time and effort in a hostile environment. Some school districts shifted from appointed school boards to elected school boards, often electing board members by geographic district rather than at large. These changes helped to reduce the likelihood that business people would serve on school boards. As a result of this anti-business bias, corporate commitment to the schools was no longer proactive and was usually restricted to cooperation with career education programs. 
In the changing educational climate of the 1980s, businesses again were welcomed participants in the school decision making process. Economic and political trends were favorable for school/business collaboration, as they had been before the 1960s. The Partnership in Education program, organized by the Reagan Administration in 1981, illustrates the renewed emphasis on school/business cooperation. The number of Adopt-A-School or Join-A-School programs increased dramatically in the 1980s (Burke 1986).

Additional evidence of this new relationship abounds. Two national organizations were formed: the National Association for IndustryEducation and the National Manpower Institute Consortium. Professional journals, including Partnerships in Education and Informedia, were published. Reports such as $A$ Nation at Risk called for businesses and other community groups to provide leadership and resources to make school reform a reality. The Committee for Economic Development, an independent, non-partisan research and education organization composed of 200 business leaders and educators, published a variety of reports, including American Business and the Public Schools, Investing In Our Children, and Children In Need.

Educators began to study these new types of school/business partnerships. The president of the American Education Research Association, in her 1987 presidential address, described how the economic and cultural aims of education could be pursued outside of school (Resnick 1987). Resnick urged educators to find ways to incorporate informally acquired knowledge into the curriculum.

Until this change in emphasis occurred, virtually all business financial support for education had gone to post-secondary institutions. However, more than 73 percent of the Fortune 500 companies have programs with the public schools. Banks, utility companies, and insurance companies are the most likely businesses to be involved in such programs (Shakeshaft and Trachtman 1986). In 1981 the National Association of Partners in Education initiated an annual symposium in cooperation with the Presidential Board of Advisors on Private Sector Initiatives. Today both business leaders and educators are interested in developing and studying these new relationships between business and education. 


\section{General Strategies for School/Business Partnerships}

In Investing In Our Children, published by the Committee for Economic Development, three types of involvement are identified: funding, program involvement, and policy involvement. Three strategies that characterize school/business partnerships are identified also:

- System Support;

- Incremental Improvement; and

- Structural Reform.

Most of the examples described in this chapter fit into the first or second strategy, System Support or Incremental Change. The type of involvement is usually either funding or program involvement. However, projects often fall into more than one category or cross the indistinct line between types of strategies or involvement. For example, projects that are classified as "program involvement" usually include some funding, although the dollar amounts tend to be smaller than "funding" projects, and the resources are usually targeted. Tables 1 and 2 categorize partnerships in place around the country and in Nebraska.

\section{System Support}

Where schools are sound, productive and successful, businesses can help to ensure their continued success by supporting the existing system. This might include funding or program involvement by participating in career education programs, providing scholarships, and sponsoring teacher recognition days. Such efforts are appropriate for maintaining existing high quality programs.

System Support Programs in Place. Job training partnerships are sponsored by the National Alliance of Businesses, with funds from the U. S. Department of Labor, the U. S. Department of Health and Human Services, the Reader's Digest Foundation, and the MacArthur Foundation, in Albuquerque, Cincinnati, Indianapolis, Louisville, Memphis, San Diego, and Seattle (Levine and Trachtman 1988).

Influenced by $A$ Nation at Risk, executives at Boeing developed a committee to support pre-collegiate education throughout Washington state. An education manager has been established at each Boeing facility in the state, and publicity about schools and educational reform is included in company newsletters. Boeing sponsors curriculum 
materials for students, career information, computer contests, and student internships, along with in-service courses and mini-grants for mathematics and science teachers. Boeing's CEO has served as chairman of the Washington Roundtable, a group of 32 corporate executive and citizens who have made recommendations about the state budget for education. Roundtable members have also promoted structural reform by presenting teacher salary proposals and supporting an expansion of the state testing program, while sponsoring time-on-task research (Levine and Trachtman 1988).

Corporations are sponsoring summer internships for teachers in Cleveland, Philadelphia, Pittsburgh, Flint, and the Silicon Valley. As summer employees, mathematics and science teachers learn new skills and information while earning extra income. The present internships are reaching only a small number of teachers, but it is believed that expanded programs could reach up to 10,000 teachers each summer. Current programs are highly praised by both teachers and employers (G. Gold 1987).

The Council of the Great City Schools surveyed its member schools to identify private sector efforts at improving school management, costeffectiveness, and productivity. In Baltimore, business executives make recommendations for school management. In Atlanta, the Chamber of Commerce has funded and conducted studies of school management. In Dallas, the school system seeks input from the private sector in the areas of personnel management, information systems, facilities utilization, and financial audits. In Dade County, Florida, local businesses assist in providing accounting procedures, training administrators, and furnishing additional consulting services (Levine and Trachtman 1988).

Forward in the Fifth is an organization of business, education, and community leaders in Kentucky's Fifth Congressional District, an economically deprived area in the southeastern part of the state. Through advisory councils in each of the 27 counties, technical and financial assistance is provided to:

- Enrich education experience for students;

- Obtain greater parental and business involvement in the schools;

- Promote innovation by school administrators and teachers; 
Table 1. National School/Business Partnerships Listed by Strategy and Type of Involvement.

System Support

Incremental Change

Structural Reform

Funding National Alliance of Businesses

Job Training Partnerships
Summer Internships for Teachers

Support for Evaluation and Research

in Minneapolis

\section{Program}

Involvement

Job Training Partnership

Forward in the Fifth Advisory Councils

School Management Training in

Various Cities

\section{Policy}

Involvement
Local School Board Participation

Lobbying State Legislatures

and Congress
North Carolina Rural Economic

Development Partnerships

Drop-Out Prevention Programs

Adopt-A-School Programs

Joint Council on Economic Education
California Business Council and Achievement Council

Washington State Roundtable

The Boston Compact (Drop-Out

Prevention and Job Skills Development)

Chicago Demonstration Schools 
Table 2. Nebraska School/Business Partnerships Listed by Strategy and Type of Involvement.

Projects with

Elements of Both

System Support

Support and Change

Incremental Change

Funding

Sutton Public Schools/Sutton

Commercial Club Partnership

Columbus School Partnerships

Junior Achievement

Buffett Awards

Kiewit Awards

Cooper Awards

Academy of Finance

\section{Program}

Hastings Chamber of Commerce/

Adams County Schools Partnership

Adopt-A-School Programs

Nebraska Council on Economic

Norfolk Business and Education

Partnership Task Force

Columbus School Partnerships

Policy

Involvement
Local School Board Participation

New Seeds for Nebraska 
- Recognize outstanding accomplishments of faculty, administrators, and students;

- Increase communication between the school and the com. munity; and

- Increase a community's confidence and commitment to the schools (Levine and Trachtman 1988).

Junior Achievement provides practical economic education through programs and experience in the private enterprise system for young people in partnership with the business and education communities. Junior Achievement of the Midlands was organized in Omaha in 1962 and in Lincoln in 1971. The original Junior Achievement program was an after-school program where students, working with local business advisers, formed mini-companies to produce and market a product or service. In 1975, JA began to develop new programs to incorporate into regular classrooms.

Three additional programs are now available from JA. Applied Economics is an elective, full credit social studies course where juniors and seniors learn economic concepts and theories as they form a simulated company and use related micro computer programs. JA has produced a textbook and related curriculum materials for Applied Economics.

Project Business is a supplementary program for junior high school students. A business consultant visits the class once a week for nine to fifteen weeks to discuss economic concepts as they relate to his or her business. There is also an emphasis on job skills in Project Business.

Business Basics introduces fifth and sixth graders to the fundamentals of organization, production, and management. Instructional materials and training for consultants are provided by Junior Achievement; nationally Junior Achievement is developing a delivery system to bring its programs to rural school systems (Some Facts About Junior Achievement 1988).

In south central Nebraska, the Hastings Chamber of Commerce and the Adams County Schools have formed a partnership. After conducting a survey to determine which schools and businesses were interested in cooperative programs, the Hastings Chamber of Commerce sponsored a workshop where participants from partnerships in other school districts shared their experiences with teachers and business leaders in 
Adams County. Initial partnerships were formed and follow-up activities were planned. "Through [this program] schools benefit from the expanded education opportunities provided when business takes a more active role... .business will be able to take advantage of a better educated, better qualified work force" (Odom 1986:6-9).

The Sutton Public Schools and the Sutton Commercial Club had developed a partnership long before the current interest in adopt-aschool programs. Activities in this partnership include fund raising for extra-curricular activities, sponsoring student recognition awards, contributing to scholarship funds, and providing athletic awards. A member of the Commerce Club attends all meetings of the school board.

In Norfolk, a Business and Education Partnership Task Force representing the Chamber of Commerce, the public and parochial schools, and local colleges was developed to create linkages between schools and businesses. Community and business leaders, trained by the Norfolk Public Schools, participate in Omnibus, the district's gifted and talented program. The Chamber sponsors an annual business, industry, and education day. Futures Unlimited, sponsored by area businesses and colleges, introduces high school students to occupations and future opportunities; Junior Achievement is provided for interested students. Limited and full partnerships with businesses have been formalized to infuse career awareness, based on community resources, across the curriculum.

The former Volunteers Coordinator and Public Information Director of the Columbus Public Schools has reported on a variety of school/business partnerships, including:

1. "Columbus Public Schools Report to Our Stockholders," an insert paid for by a local bank, that appears in the Columbus Telegram four times per year.

2. Omnibus units for the gifted and talented students taught by representatives from the radio station and a local bank.

3. Luncheons for business and education leaders, and sponsorship of vocational education and economic education workshops for teachers.

4. Creation of a "blue ribbon panel of community leaders who [meet] to discuss the opportunities and roadblocks in regard 
to the business and education sectors working together in the community" (Odom 1986).

Several Nebraska foundations have developed programs to honor outstanding teachers and provide financial rewards as well as public recognition for their classroom performance. Each spring a group of outstanding teachers is recognized by the Buffett Foundation in Omaha and the Kiewit Foundation across the state. The Cooper Foundation has established the statewide Cooper Awards, which honor teachers for curriculum development in the areas of history, economics, mathematics, science, foreign language, and communications. Because the awards are given to educators who create innovative projects, these programs also support incremental improvement.

\section{Incremental Improvement}

The second strategy, incremental improvement, requires businesses to support more obvious school reforms such as supporting teacher incentives or merit pay, providing leadership training for administrators, or calling for competency testing for students. Responses at this level are based on stronger corporate decisions to become involved in educational reform, including a willingness to sponsor specific projects. At this level, important questions about the role of private sectors in public education begin to emerge.

Incremental Improvement Programs in Place. Dropout prevention programs were funded by Hewlett Packard for Santa Clara, California schools; by Rich's Department Store in Atlanta; and by Digital Equipment in Oxford, Massachusetts.

Some school/business partnerships in rural areas combine school and work efforts with rural economic development. The Way Off Broadway Deli in St. Pauls, North Carolina, and the Hurricane Screen Printing Company in Gumberry, North Carolina, are examples of school- and business-supported student entrepreneurial projects. As a result of participation, it is hoped that students will have employment options when they graduate. Those who leave will have employment skills; those who stay in their home towns will be able to earn a reasonable income ( $A$ New Idea for Rural Youth 1988).

The Academy of Finance, part of a national program supported by the American Express Foundation, provides a two-year program in finance for high school juniors and seniors. In the Omaha Public 
Schools, businesses, schools, parents, and students work together to reach the following outcomes:

- Make students aware of career opportunities and provide them with skills necessary for work in the financial service industry;

- Increase students' knowledge and appreciation of basic financial concepts;

- Help students understand the relationship between the American economic system and the world of finance; and

- Provide on-the-job training to help students apply what they learn in class.

Students who enroll in this program must demonstrate competencies in accounting and computer science, have an interest in the financial services industry, be willing to commit to the two-year program and a summer internship, and be nominated by their teachers. While the major financial costs are provided by the American Express Foundation and the Omaha Public Schools, local businesses provide the internships and local business leaders along with educators serve on the advisory committee (OPS Academy of Finance Model Program 1988).

The Adopt-A-School program, developed in 1983 by the Omaha Public Schools' Department of Human-Community Relations Services, is based on national programs designed to foster closer relationships between public schools and the business community that will help resolve the challenges facing the urban school districts. It represents both system support and incremental improvement. The goals for this school/business partnership are to:

- Plan and implement a program which helps students to compete more successfully in modern society; and

- Improve administrative-managerial activities through application of combined professional expertise.

Included on the current list of over 100 business partners are major national corporations, banks and other financial institutions, civic groups, grocery stores, hospitals, hotels, fast food restaurants, and small businesses.

As a school partner, the business or community group may provide tutors and teacher aides, transportation, field trips and special recogni- 
tion events, internships, and career seminars. As a business partner, the local school may provide music programs and art displays at a business site, job skills training and human relations training, reduced admission to school programs, and the use of other school facilities (Kehrberg 1988).

In 1987, the Lincoln Chamber of Commerce Education Committee in cooperation with the Lincoln Public Schools created Ventures in Partnerships (V.I.P.), an adopt-a-school program. Over 40 partnerships were established by the end of the 1987-88 school year. V.I.P. gives students and teachers a realistic awareness of the job market and provides a mechanism for businesses and schools to share expertise and services. In addition to increasing communication and understanding between schools and businesses, the program supplies role models for students, improves students' attitude about school, and encourages them to earn a diploma. Student employability is enhanced because regular contact with schools helps to keep the curriculum compatible with existing jobs and with the expectations of businesses (Ventures in Partnerships Handbook).

The Nebraska Council on Economic Education, based at UNL, works through Centers for Economic Education at UNL, UNO, Kearney State, Chadron State, Wayne State, Peru State, and Doane College to increase the economic literacy of $\mathrm{K}-12$ students across the state. The Council raises funds, primarily from the private sector, to support teacher training courses and workshops in addition to the development and/or dissemination of new curriculum materials. The Council is affiliated with the Joint Council on Economic Education and its network of Councils and Centers across the country.

The majority of the Council's resources are directed toward teachers. The Council's programs are based on the philosophy that it is most economical to train teachers and provide them with appropriate curriculum materials so that they may help students understand the American economic system and their roles as producers, consumers, and citizens. In the 1988-89 school year, the Council sponsored 38 workshops and courses that were attended by over 1,300 Nebraska teachers (Annual Report 1989). In the most recent session of the legislature, business sponsorship was primarily responsible for partial state funding of the Council's programs. 


\section{Structural Reform}

Structural Reform, the third level of involvement, reflects the view that basic policy changes must occur in the public schools if the schools are to deliver quality education and provide citizens and workers who can prosper in the 21st Century. There are currently few school/business partnerships at this level and little of this kind of policy involvement.

Structural Reform Programs in Place. One structural reform program was funded by General Mills, which provided $\$ 350,000$ to the Minneapolis Schools to evaluate educational reform in selected Minneapolis elementary schools. Included in the reforms being evaluated are: determining the impact of smaller class size on student achievement, fostering twacher decision-making, and increasing parental involvement in schools (D. Gold 1988).

Rccommendations were made for better serving the diverse student populations of the public schools by the California Business Council and the Achievement Council, a consortium of representatives from the larges! corporations in the state. The consortium is particularly concerned about why minority and inner city students lag behind in acadenic achievement (Snider 1988).

One of the earliest and most widely publicized structural reform programs is the Boston Compact, developed by the Boston Public School System and 350 Boston businesses under the leadership of the Boston Federal Reserve Bank. High dropout rates and graduates inadequately prepared for college or the work force had become problems for the Boston economy, with its increasing demand for skilled workers in an overall shrinking labor market. Through the Compact, the business community, the public schools, universities, cultural organizations, and unions have been organized to focus the resources of a broad range of institutions on Boston's teenagers (Hargroves 1987).

In Chicago a new private demonstration school was designed to match the constraints of an inner-city public school and to be a research and divelopment laboratory for improving urban education. Sears, Roebuck \& Co.; United Airlines; Commonwealth Edison; Baxter International; and 12 other corporations invested more than $\$ 2$ million to create this elementary school as a model for educating inner-city children ("Chicago Schools Offered a Lesson by Corporations" 1988). 


\section{Nebraska Partnerships}

It appears that the school/business partnerships currently in place across Nebraska are quite similar to those in other states. Most partnerships provide system support or promote incremental change through funding or program involvement. There are few examples of Nebraska partnerships designed to promote major structural reform; there is only limited policy involvement. Virtually all of the projects have been estab. lished in the metropolitan areas or in the larger cities across the state. The cooperating businesses tend to come from the manufacturing and/or service sectors of the economy. Two possible explanations for the lack of agriculture-based partnerships may be that: (1) agriculture is not as highly organized as the other two areas; and (2) the employment opportunities for students in agriculture have decreased and will continue to decrease. There appear to be few partnerships in rural areas to promote economic development like those described in North Carolina and Kentucky.

Another difference between Nebraska and states that have more extensive school/business partnerships is the nature of the big city public schools in those states. Schools in Nebraska, even though they face the problems of drugs, violence, dropouts, at-risk students, and teenage pregnancy, do not face these problems to the degree that many urban schools do. Since the schools in Nebraska have not collapsed under the weight of these problems, there appears to be less need for businesses to become involved in school reform through partnerships.

Many of the major national school/business partnerships have been created in the cities where major corporations are headquartered. As there are very few Fortune 500 companies based in Nebraska, this reduces the extent and comprehensiveness of partnerships in the state.

In some states (California, Washington and Minnesota) businesses have formed independent consortia to examine the schools and make policy recommendations to the state government. In 1989, for the first time, this has begun to occur in Nebraska. Nebraska Futures, Inc. (NFI), the business-engendered corporation formed to implement the recommendations of New Seeds for Nebraska (Center for Economic Competitiveness 1987), has included proposals for structural changes to the schools in its recommendations for economic development. The Subcommittee on Curriculum of NFI's Human Resources Task Force made three proposals that constitute a real departure from the previously 
established relationship between business and the schools. The Subcommittee proposed:

(1) A complete review of the governance and organization of the Nebraska educational establishment, to include examination of funding, degree of local control, role of the Department of Education, and accreditation of teachers and teachers colleges.

(2) A complete restructure of Nebraska schools beginning with the curriculum, based on a "new basics" curriculum to be adopted by all Nebraska schools.

(3) Establishment of a greater level of accountability in the school systems of the state through a method of evaluating schools and teachers based solely on performance and achievement of students.

If even a part of these proposals is acted upon, it will indicate a radical change in the role of the business community in school affairs in Nebraska.

\section{The Nature of Current Business Involvement in the Schools}

A company's willingness to become involved in partnerships with the public schools is often constrained by the company's size, wealth, growth potential, sense of civic responsibility, level of technology, need for trained employees, and non-financial resources that it can offer to schools (Levine and Trachtman 1988).

Mann summarizes the potential contributions of business partners in this way:

\footnotetext{
The assistance offered by the business community will come from the areas business knows best: food services, payroll processing, security, public relations, auditing, capital budget projections, lectures by volunteers, field trips, and perhaps some scholarships or reserved positions for new graduates. There will be no unrestricted gifts and not much appetite for engaging the central problems of schooling. No superintendent will ask for and no business executive will promise to provide what cannot be delivered. (1987)
}

Virtually all business philanthropy to schools takes the form of a project; businesses are most willing to fund discrete activities with clearly defined goals. They choose projects that they can afford, and they seek projects that emphasize public sector and private sector coopera- 
tion, avoiding projects that may foster conflict and controversy. These projects are usually not advocacy oriented, but are built on existing mutual interests, such as reducing the drop-out rate or improving workers' entry level skills. This search for cooperation may explain why most partnerships concentrate their efforts on system support or incremental change and avoid projects that attempt to promote structural reform (Mann 1987).

A further constraint on systemic reform is the changing pattern of philanthropy in the economic sector. Currently, the industrial sector of our economy targets 46 percent of its overall giving to education-related activities, while the expanding service sector targets only 25 percent of its philanthropy to education.

The total value of grants, goods, and services provided by businesses to schools is around $\$ 28$ million, a small fraction of the educational budgets of those districts (Levine and Trachtman 1988). In addition, there are other philanthropic interests competing for the business community's financial support. Businesses seek to develop broad-based community satisfaction by contributing to many of these interests as well as education.

In a study of 85 rural school districts, Trachtman reported that while some superintendents in small or rural districts welcomed increased business involvement in the schools, many school administrators had strong reservations about additional involvement (Levine and Trachtman 1988). Some school administrators fear that widely publicized, privately supported programs may confuse voters and weaken support for raising additional tax revenues to support schools. Furthermore, there is always competition for funds and partnerships with other groups - the band boosters, Scouts, the school yearbook, or the elementary school candy sales-and school administrators don't want to jeopardize these. This is especially true in school districts outside of large cities.

Finally, some business leaders are concerned about whether just providing more financial support to schools will bring about needed improvements. The total economic and social costs of some educational problems, such as the economic and social costs of dealing with the 700,000 students who drop out each year, may be so high that private sector support will be too limited to be effective. In addition to increased financial support, successful responses to such problems may include major long-term changes in the education system. But changes carry the 
prospect of conflict and controversy, two characteristics that private supporters of public education seek to avoid. Business is more willing to support projects that ameliorate, not reform. Projects tend to be "low cost, low conflict, peripheral, and largely focused on the middle class" (Levine and Trachtman 1988).

Most of the financial support from the business community will continue to come from taxes on business. However, private support can be used to narrow the gap between needs and available resources through funding of experimental programs, special projects, and research and development efforts. At the federal level, less than 1 percent of the education budget is invested in research and development. Some business leaders have urged that additional funds be made available for elementary and especially preschool programs, such as Head Start; improving the teaching of reading, math, and science in the middle grades; assisting at-risk kids; and creating job training programs-as well as supporting research to foster productivity gains (Levine and Trachtman 1988).

Some corporate leaders, especially those affiliated with the Committee for Economic Development, have called for increased public spending on education. The committee believes "that any call for comprehensive improvement in the public schools that does not recognize the need for additional resources is destined for failure" (Investing in Our Children 1985). These leaders encourage the corporate community to become advocates for public schools at the local level. According to one survey, 72 percent of chief executive officers support additional federal aid to elementary and secondary education (Shakeshaft and Trachtman 1986). While there has been a heightened awareness of public school needs, 70 to 75 percent of the educational contributions of large corporations are still directed toward higher education (Corporate Gifts 1988).

Unfortunately, the business community has sometimes called for reforms on the one hand while lobbying against tax increases and bond issues on the other. Fred Hechinger, educational columnist for The New York Times, wrote in the Harvard Business Review:

\footnotetext{
In the end, all these cooperative ventures will amount to little more than public relations unless the business community abandons its frequently schizophrenic posture; supporting the local schools while simultaneously instructing, or at least permitting, its lobbyists to support cuts in state and federal expenditures for public education and such legislation as tax credits for parents whose children attend private schools. Common sense should show the futility of any corporate policy that gives to the local schools with one hand and yet takes away funds with the other. (1985:136-144)
} 


\section{Partnerships in Small Communities and Rural Areas}

Most of the widely publicized school/business partnerships were developed in large, urban school districts. There is much less information about partnerships in smaller towns and rural areas. Even the Omaha and Lincoln public schools are quite different from the public schools in Boston, Chicago, New York City, or Atlanta, in terms of the problems facing urban school districts. Therefore, partnership models that address the unique features of Nebraska's schools-urban districts as well as small rural districts-need to be developed.

The Heartland Center for Leadership Development, a Lincolnbased consulting firm, "has visited, studied, and described communities that are meeting the challenge to survive with creative, positive, problem-solving approaches. " Wall and Luther, two of the Center's researchers, have identified 10 strategies for making connections between schools and businesses in small communities.

1. Chamber-School Committee Membership. Appoint educators to Chamber of Commerce committees; appoint business people to school committees. Ask participants occasionally to report to their respective boards on what they are doing.

2. Joint School Board-Chamber Meetings. Schedule regularly a joint meeting of the School Board and the Chamber of Commerce to share information relevant to economic development.

3. Economic Surveys by School Classes. Ask high school classes or clubs to conduct community surveys to help determine current economic activities, trends, and projections.

4. Career Awareness Days. Ask local employers to act as "mentors for a day" for high school students as a means of career exploration.

5. Teacher-Business Exchanges. Sponsor a one-day "job exchange" program, asking teachers to work in businesses and business people to work in schools. Hold a follow-up discussion.

6. Entrepreneurship Education. Sponsor a class in the high school on starting and operating a small business, with guest 
speakers from local businesses as an integral part of the instructional plan.

7. School Facilities as Incubators. Make available under-utilized school facilities as small business incubators. Hire students to provide support services.

8. School-Based Businesses. Initiate a program that will help students explore, start, and operate businesses filling gaps in available local services.

9. Joint Economic Development Planning. Ask the School Board, County Board, Town Council, and Chamber of Commerce to develop a joint area economic development action plan, using the unique strengths and contributions of each partner.

10. Public-Private Partnership Leadership Development. Develop a public-private partnership for leadership development, focusing the program on developing local capacity and nurturing local resources that are critical to economic renewal (1988).

The researchers recommend that a partnership should develop small, workable, success-oriented projects. They also emphasize that schools in rural communities may be the largest resource base in the community, so they may need to take the initiative in developing partnerships. Accessibility to, and familiarity among, school leaders and business leaders should facilitate partnerships in rural areas. The existing relationships between schools and businesses may already be quite healthy, providing the basis for additional program development.

Trachtman also reported on the extent of partnership programs in rural areas. She concluded that:

1. The amount of direct financial support, excluding taxes, is minimal.

2. Most of the involvement is in vocational classes. However, this tends to be broad-based vocational education, not a focus on specific job skills. 
3. Partnerships are initiated by the school, not the business. The initiator is usually a resourceful teacher, not a school ad. ministrator.

4. The benefits of partnerships usually accrue to the teacher and his or her students, not the district. The district may not be fully aware of the partnership, as there is usually little publicity about the partnership.

5. Teachers involved in partnerships feel more connection with the outside world; they identify mutual concerns shared with local business interests. Their self-esteem is generally enhanced.

6. Superintendents report little involvement in school/business partnerships, though they do recognize the potential for such partnerships. (Levine and Trachtman 1988).

While it is too early to determine if partnerships in small or rural school districts will lead to systematic education change, Trachtman urged principals to become more informed about and more involved in creating local partnerships. She called for expanding partnerships beyond the high school into the elementary, middle, and junior high schools and providing counselors with better community job-related information. As teachers who are currently involved in school/business partnerships are responding to local needs, their involvement should be recognized and rewarded within the district.

\section{Compatibility with the Curriculum}

Partnerships do not appear to threaten school integrity. To the extent that one can generalize from community to community, businesses have not shown much evidence of demanding specific programs that would shift the costs of job-specific training from the private to the public sector. Proctor and Gamble does not dominate the curriculum of the Cincinnati Public Schools, nor does Toyota dominate the curriculum of the Hayward, California, Public Schools. Narrow, job-specific vocational education is rejected; schools are encouraged to develop students' academic abilities and develop appropriate work- related attitudes. In those areas where the dropout rate is high, the private sector has encouraged the schools to develop programs to prepare at-risk students for employment and for higher education. There is little reason to 
believe that curricula will be focused to meet the specific needs of the business partners.

According to De Young, many mainstream economists as well as some education reformers believe "that public schools are and by definition will remain inefficient places to teach occupational skills" (1989). Some economists believe that only by making these entrenched bureaucracies subject to market forces will reform occur. Radical economists stress the problems of developing worker skills in schools under siege by business leaders who are not interested in making the workplace more democratic and opening up the economy to full participation for disenfranchised groups (DeYoung 1989).

\section{Some Policy Recommendations}

Because of the great number of small town and rural school districts in Nebraska, attention must be focused on schools as large resource bases for community economic development efforts. Although rural areas have not traditionally supported school-business partnerships and rural school administrators have often had strong reservations about organized business involvement in local education policy, there are many reasons why a new approach to school-business partnerships ought to be considered, and many approaches to be tried.

First, there is a need to move beyond the case-by-case, project-byproject approach, to a more systematic use of business resources in education. Even the federal government has encountered the limits of special projects as a method for reforming education. However, moving beyond the project approach will be difficult because businesses strongly favor this approach, which identifies them with a school or a program and provides good public relations. Moreover, businesses have a long history of sponsoring specific community projects.

Second, rural communities can use their schools as resources for economic development. Those strategies developed by the Heartland Center, which open communication and share resources among schools and businesses, are particularly appropriate to Nebraska's rural districts.

Finally, working through business consortia or trade associations is another viable way to broaden business involvement. School administrators may need to educate the private sector of the importance of longterm, general support for school reform. Additionally, new intermediary organizations like the California Roundtable may need to be created. 
The business community-not only within each community, but across the state-has the knowledge and skill needed to be invested in community schools. Because small community growth and development are necessary for the economic welfare of the entire state, the results of school-business partnerships are potentially beneficial to the entire business community of Nebraska.

\section{References}

Annual Report. 1989. Lincoln, NE: Nebraska Council on Economic Education.

Burke, M. A. 1986. "School-Business Partnership: Trojan Horse or Manna from Heaven." NASSP Journal, 70(493).

Center for Economic Competitiveness. 1987. New Seeds for Nebraska: Strategies for Building the Next Economy. Menlo Park, CA: SRI International.

"Chicago Schools Offered a Lesson by Corporation." 1988. Omaha World Herald, April 22: 14.

Children in Need. 1987. New York, NY: Council for Economic Development.

"Corporate Gifts to Schools Rising." 1988. Education Week, 5 (January 13).

DeYoung, A. J. 1989. Economics and American Education. New York: Longman Inc.

Farrar, E. 1986. "Business Involvement in School Improvement: The Case of the Boston Compact." Washington, DC: U.S. Department of Education, Office of Education Research and Improve. ment.

Finn, C. E., Jr. 1987. "Education That Works: Make the Schools Complete." Harvard Business Review, (September-October).

Gold, D. L. 1988. "Firm to Fund Model School in Minneapolis." Education Week, 8 (March 9).

Gold, G. G. 1987. "A Reform Strategy for Education: Employer-Sponsored Teacher Internships." Phi Delta Kappan, 5(January).

Hargroves, J. S. 1987. "The Boston Compact: Facing the Challenge of School Dropouts." Education and Urban Society, 19.

Hechinger, F. M. 1985. "Turnaround for the Public Schools." Harvard Business Review, (1):136-144.

Investing in Our Children: Business and the Public Schools. 1985. New York: Committee for Economic Development.

Kearns, D. T. 1988. "An Educational Recovery Plan for America." Phi Delta Kappan, (April): 565570.

Kehrberg, R. 1988. Interview with author, September.

Levine, M., and R. Trachtman (Eds.) 1988. American Business and the Public Schools: Case Studies of Corporate Involvement in Public Schools. New York: Committee for Fconomic Development.

Mann, D. 1987. "Business Involvement and Public School Improvement." Phi Delta Kappan, 3.

A Nation At Risk. 1983. Washington, DC: National Commission on Excellence in Education. 
Neikirk, W. R. 1988. "Education Change Is Up To Business." Chicago Tribune, (May 5).

Odom, B. A. 1986. "Business-Education Partnerships Growing." Nebraska School Leader, 2: 6-9. OPS Academy of Finance Model Program. 1988. Omaha, NE: Omaha Public Schools.

"A New Idea for Rural Youth: Don't Leave Town, Stay at Home and Start Your Own Business." 1988. Work America, (March).

Resnick, L. B. 1987. "Learning In and Out of Schools." Educational Researcher, 16 (9).

"Rural Partnership Encouraged." Nebraska School Leader, 5(2).

Shakeshaft, C., and R. Trachtman. 1986. "Business as Usual: Exploring Private Sector Participation in American Public Schools." (Paper presented at American Education Research Association). San Francisco, April.

Snider, W. 1988. "Small Changes Won't Do, Says California Panel." Education Week: 1 (June 8). Some Facts About Junior Achievement. 1988. Omaha, NE: Junior Achievement of the Midlands. Starr, M. K. (Ed.) 1988. Global Competitiveness. New York: American Assembly. Venture's in Partnerships Handbook. N.D. Lincoln, NE: Lincoln Chamber of Commerce.

Wall, M., and V. Luther. 1988. "Rural Schools and Economic Development: Making the Connection." Nebraska School Leader, 7 (Spring). 